\title{
Diagnosis of the Cost System in SME companies in the textile sector of South Sonora, Mexico
}

\section{Diagnóstico del Sistema de Costos en empresas Mypmes del sector textil del Sur de Sonora, México}

MILLANES-MORENO, María Dolores广**, RUIZ-PEREZ, Roberto, VALENZUELA-REYNAGA, Rodolfo and VÁZQUEZ-JIMENEZ, Imelda Lorena

Instituto Tecnológico de Sonora, Departamento de Contaduría y Finanzas

ID $1^{\text {st }}$ Author: María Dolores, Millanes-Moreno / ORC ID: 0000-0003-0772-2930, CVU CONACYT ID: 688327

ID $1^{\text {st }}$ Coauthor: Roberto, Ruiz-Perez / ORC ID: 0000-0001-8884-9890, CVU CONACYT ID: 625356

ID $2^{\text {nd }}$ Coauthor: Rodolfo, Valenzuela-Reynaga / ORC ID: 0000-0003-3408-361X, CVU CONACYT ID: 287601

ID $3^{\text {rd }}$ Coauthor: Imelda Lorena, Vázquez-Jimenez / ORC ID: 0000-0002-3716-328X, CVU CONACYT ID: 287385

DOI: $10.35429 / \mathrm{JBAB} \cdot 2019.4 .3 .1 .8$

Received March 18, 2019; Accepted Juen 30, 2019

\begin{abstract}
The objective of this work is to diagnose the current situation of the Mypmes of the textile sector of the South of Sonora for the determination of how the financial administrator can make decisions through the analysis of the environment and the veracity of the information that the cost system throws, and with it facilitate the development of possible solutions that maximize the profitability of companies. The research has two approaches: qualitative for the characterization of the phenomenon and quantitative for the causal relationships between the variables under study. The study is exploratory, since it works on knowledge gaps that have different results depending on the context; It is descriptive because specific results of microenterprises are shown. The research is non-experimental, since there is no control over the variables. The instrument was designed based on the National Survey on Productivity and Competitiveness of Micro, Small and Medium Enterprises (ENAPROCE) 2015. The SPSS and SmartPLS were used to determine the causal relationships and validation of the instrument's reliability, as well as the verification of the hypotheses. It contributes to the promotion of applied research in regional issues for possible solutions associated with the well-being of organizations.
\end{abstract}

Cost System, Financial Administrator, Accuracy of Financial Information

\begin{abstract}
Resumen
El objetivo de este trabajo es diagnosticar la situación actual de las Mypmes del sector textil del Sur de Sonora para la determinación de cómo el administrador financiero pude tomar decisiones a través del análisis del entorno y la veracidad de la información que arroja el sistema de costos, y con ello facilitar la elaboración de posibles soluciones que maximicen la rentabilidad de las empresas. La investigación tiene dos enfoques: cualitativo para la caracterización del fenómeno y el cuantitativo para las relaciones causales entre las variables objeto de estudio. El estudio es exploratorio, ya que se trabaja sobre brechas del conocimiento que tienen diferentes resultados según el contexto; es descriptivo porque se muestran resultados específicos de las microempresas. La investigación es no experimental, ya que no se tiene control sobre las variables. El instrumento se diseñó tomando como referencia la Encuesta Nacional sobre Productividad y Competitividad de las Micro, Pequeñas y Medianas Empresas (ENAPROCE) 2015. Se utilizaron el SPSS y el SmartPLS para determinar las relaciones causales y validación de confiabilidad del instrumento, así como la comprobación de las hipótesis. Se contribuye al fomento de la investigación aplicada en problemáticas regionales para posibles soluciones asociadas al bienestar de las organizaciones.
\end{abstract}

Sistema de Costos, Administrador Financiero, Veracidad de la información Financiera

Citation: MILLANES-MORENO, María Dolores, RUIZ-PEREZ, Roberto, VALENZUELA-REYNAGA, Rodolfo and VÁZQUEZ-JIMENEZ, Imelda Lorena. Diagnosis of the Cost System in SME companies in the textile sector of South Sonora, Mexico. Journal-Business Administration-Marketing; Accounting. 2019. 3-4: 1-8

\footnotetext{
* Correspondence to Author (email: mmoreno@itson.edu.mx)

$\uparrow$ Researcher contributing as first author
} 


\section{Introduction}

Current market conditions demand that companies be more competitive, thereby facilitating opportunities for commercial success in a globalized environment, as stated by Monge (2010). The relevance of developing these research works provide guidelines for Mpymes to make decisions that are aimed at improving their monetary performance, which will result in returns.

The research is carried out in southern Sonora, specifically in the municipality of Cajeme where Mpymes of the textile sector have an important participation in the economic growth of the region. This is supported by the portal of the Government of the State of Sonora (2016) in the 2016 Annual Work Report of Sonora in which it states that in that year 30 investment projects were carried out which will generate 9,743 new jobs and an investment of 337 million dollars with resources from different countries in Europe, North America and Asia, benefiting the most important municipalities of Sonora. Among the main sectors that received support are: aerospace, agribusiness, textiles, among others.

The central problem of the investigation is that a financial administrator through the use of a cost system could explain through causal relationships how a company in the textile sector could make better decisions analyzing the environment and the veracity of the reports it produces. the same (Cedeño, F., Coloma, R., and Zamora, V., 2016; Ríos, M., 2014; Román, C. 2012). This establishes two basic hypotheses.

H1: The Financial Administrator through the cost system positively impacts the economic performance of the organization with the use of environmental analysis.

H2: The Financial Administrator through the cost system positively impacts the economic performance of the organization with the use of truthful information.

Posing the problem and establishing the hypotheses, the following general objective can be established.
Diagnose the current situation of the Mypmes of the textile sector of southern Sonora for the determination of how the financial manager can make decisions through the analysis of the environment and the veracity of the information provided by the cost system, and thereby facilitate the preparation of possible solutions that maximize the profitability and performance of companies.

To facilitate the understanding of this work, it is convenient to mention its structure, which is organized in six sections: Introduction, Theoretical Framework, Methodology, Results, Conclusions and References.

The Introduction section shows a brief history of the phenomenon under study, as well as its geographical contextualization. It also exposes the problem to be developed, the hypotheses to be tested, as well as the general objective.

In the second section, a review of the literature regarding the three study variables in the research is developed, as well as its conceptualization through previous research. This point is about establishing the starting framework for the operationalization and characterization of the phenomenon.

The third section systematically recounts the methodology used to collect and analyze the information obtained, as well as the quantitative methods used to achieve the objectives set.

In the fourth section the results obtained derived from the analyzes performed are presented, in order to open a preamble in the establishment of causal relationships and the determination of the statistical contribution.

The conclusions section shows whether the hypothetical relationships raised at the beginning are fulfilled, or not. In the same way future research is proposed.

Finally, in the references section, all the sources that were consulted for the realization of this investigation are listed. 


\section{Theoretical framework}

The textile industry is one of the main sources of income and employment for many countries, especially those in development, this type of industry at the global level was among the first to develop and thereby revolutionized its entire environment, generating an increase in serial work According to Angulo (2001, p.1) "the textile industry represented up to $2.5 \%$ of world merchandise trade and $3.3 \%$ of world manufacturing trade in 2001 ".

In Mexico, "the textile industry began to be recognized since 1830, 4 modern spinning factories were created in Puebla with 8,000 spindles in 1837 and by 1844 there were already 47 factories with 113,813 spindles in the country" (Arroyo \& Cárcamo, 2010). Industrial development in Mexico in recent years has been paralyzed due to three factors that Díaz (2005) mentions: "firstly the competitiveness of the Chinese economy, secondly the loss of competitiveness of the Mexican economy and, finally, fiscal reforms to the Income Tax implemented to wages and salaries". This third factor has mostly affected the demanding sectors with intensive human resources, such as factories and maquiladoras.

Sonora, is a state in the northwest of the country which is diversified in terms of economy, mainly concentrated in primary activities such as agriculture, mining, forestry and fishing. The textile industry is implemented in Sonora from the structural change made in the seventies, when the primary sector declines as the axis around which its economy revolved, and manufacturing activity and services begin to gain importance as the authors comment Lara, Velásquez and Rodríguez (2007).

According to the National Institute of Statistics, Geography and Informatics (INEGI), "in the years from 1993 to 2004, the economy of Sonora was the smallest in the context of the northern states of Mexico, and was also the least dynamic of the gross domestic product (GDP) "cited by Díaz (2009) pp: 47.

ProMéxico with information from INEGI (2018), indicates that 1 in 10 jobs in the manufacturing industry is that of the textile and clothing sector, in 2017 alone 181,648 jobs were generated in the Mexican Republic and 1,521 university graduates with related careers.
Textile companies represent $64 \%$ of the total sector in Mexico, with a production of \$ 84,877 million pesos only in 2017 , the state with the highest textile production is the State of Mexico with $20.10 \%$ of the total, followed by the City of Mexico with $17.20 \%$ and Puebla with $11.40 \%$. In exports Coahuila took first place with an equivalent to $15.10 \%$ of the total, following Puebla with $11.60 \%$ and Baja California with $8.70 \%$. (ProMéxico, 2017)

\section{Classification of cost systems}

The classification of cost systems can be based on the date you get the information, these can be historical or predetermined. According to Reyes (2016) "historical or real costs are obtained at the time the product has been prepared", while Del Río (2004) defines them as "consummated facts which provide data for control, planning and taking of decisions".

Continuing with the predetermined costs that Ortega (2012) defines as "the costs that are born in the termination of the product and even before its production", these are divided in turn into estimates and standard. García (2014) explains that the estimates "project how much a product or the operation of a product can cost for a given period", these types of costs are calculated based on the experience of previous productions of the person who is calculating them. While the standard costs are how much the product should cost, based on the scientific method.

Cost systems can also be classified according to the way they operate: absorbent or direct. Gómez (2005) defines absorbents as those that "include the costs of direct raw material, direct labor and fixed and variable indirect manufacturing costs", on the other hand, Huicochea (2010) declares that the direct ones "do not include fixed or periodic costs and do not require apportionments, because the unit cost of the product only accumulates those costs that have a direct identification with the product".

A final classification is based on the production characteristics of the company, which are divided into production orders or production processes. 
The first Horngren, Datar and Rajan (2012) identify them by "work orders that, in general, use different amounts of resources having the ability to divide costs for each batch manufactured", and the second, "is used in industries whose production is continuous and mass, where there is one or several processes of transformation of matter "(Reyes, 2016).

\section{The Financial Administrator (Y1)}

The financial administrator of the organization has as one of its maxims to ensure the achievement of previously set objectives. To do this, he uses various tools that facilitate decision making. One of the main functions is to use an adequate cost system, since from this you can do planning activities, merchandise acquisition, waste management, among others and with this you contribute to the maximization of the agent's monetary resources economic. With a good cost system, the financial administrator is enabled to be able to make forecasts for the preparation of the company's financial plans and thus a decrease in financial uncertainty is achieved, since it monitors the possible scenarios to which could face.

\section{Decision making and cost system}

Ríos (2014) highlights the importance of cost systems as they provide information for the design of products and services, as well as the outline of tools such as continuous improvement to help in making decisions regarding investment, reengineering and even in the pricing cited by González, Aceves, López, Navarro and Moreno (2018) pp: 22 Thus, in companies it is vitally important to help themselves with those tools that provide useful information that can support decision-making for the improvement of their administration, so that each company must adapt its cost system according to Your own needs and characteristics.

\section{Type of decisions that can be made}

One of the main objectives in determining costs is to offer information for decision making. Companies have various strategy options when determining costs, but according to Merlo, Reinoso, Rubino and Ruggeri (2013), they should aim to make decisions regarding three fundamental factors:
Clients in which they will concentrate; Products or services you will offer; Activities to perform.

By taking action on the three aspects above, the organization can be helped to reach the total quality of its products and services and, likewise, reduce their costs.

\section{The environment analysis (X1)}

In publications made by Guerrero (2004) he mentions that the dynamism that organizations face has caused greater competition derived from the phenomenon of globalization; in such a way that organizations have to incorporate internal and external variables into their planning and costing mechanisms; This is the analysis of the environment to consider what effects they could have on the performance of the company.

Similarly, Gomez and Herrera (2014) state that the changes that occur in the environment trigger changes within the company. They detected that some of the main conditions of the business environment are: variables of consumption and demography, economic, technological, labor, ecological, regulatory and relevant markets. For the purposes of this investigation, the analysis of the environment will be used to determine how they affect the decisions of the financial administrator.

\section{The veracity of the information (X2)}

In accordance with Financial Information Standard A-4, financial information has the quality of reliability when "the content is consistent with the transactions, internal transformations and events that occurred, and the general user uses it to make decisions based on this characteristic" and It will be true when the events mentioned above and other events have happened. For the purposes of this investigation, the veracity of the information will be used for the cost system. (Rincón and Fernando, 2010; Rincón, Lasso and Parrado, 2012).

The veracity of the information serves to solve problems and make corrective or future decisions. In the same way, they propose scenarios in which the organization would be in a better chance of success. 
When the information is not truthful, action programs can be made that are not attacking the need or area of opportunity detected, thereby achieving a decrease in profitability (Rincón y Fernando, 2010).

\section{Methodology to be developed}

The research approach is quantitative. Causal relationships are proposed between the variables under study. The analysis is exploratory since it works on knowledge gaps that have different results depending on the context; It is descriptive because specific results of microenterprises are shown. The research is non-experimental, since there is no control over the variables.

\section{Instrument:}

The instrument was designed taking as reference the National Survey on Productivity and Competitiveness of Micro, Small and Medium Enterprises (ENAPROCE) 2015. As well as adaptations of Ríos contents (2014) on "Diagnostic Method to Determine the Cost System in a Pyme" and the work of Del Río, C., Del Río, C. and Del Río, R. (2011) Costs I. To give greater certainty to the application of the instrument, each interviewer was asked to take a picture of the place you visited.

\section{Population:}

The population was taken as reference information provided by the National Statistical Directory of Economic Units (2019) of the INEGI, which shows that in the municipality of Cajeme, Sonora there are 77 companies dedicated to the manufacture of clothing and clothing manufacturing / clothing accessories and other garments, of which applying the Sampieri formula with 67 companies surveyed obtains a reliability of $97 \%$.

\section{Inferential Statistics}

The SPSS 21 Software was used to calculate the reliability of the instrument through Cronbach's Alpha and the SmartPLS to determine the causal relationships and validation of the instrument's reliability, as well as the hypothesis testing. For the statistical tests the square $\mathrm{R}$, Beta Coefficients, the $\mathrm{P}$ Value (significance) and the Statistical $t$ were taken.

\section{Results}

Derived from the application and systematization of the instrument applied, the following results were obtained:

Cronbach alphas:

Being an instrument adapted from an INEGI CENSUS, its reliability should be obtained at high levels (greater than 0.7), which is consistent with the results obtained, each of the three variables met the criteria: Financial Administrator (0.9); Analysis of the Environment (0.94) and Veracity of the Information (0.9). Which indicates that the respondents had no confusion with the questions.

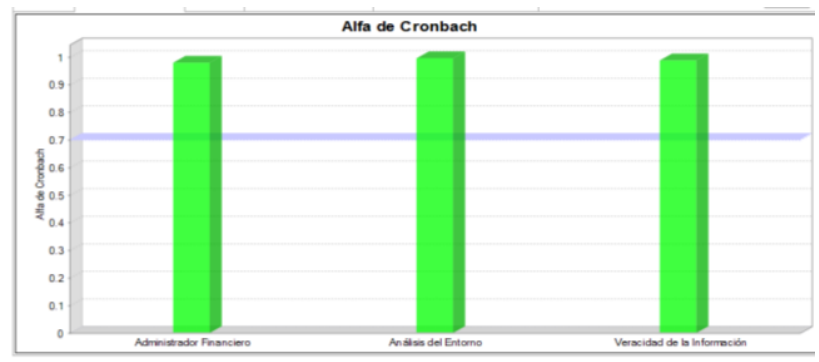

Figure 1 Cronbach's Alpha

Own elaboration with SmartPLS, 2019

R square:

It reveals the capacity of explanation of the model, that is why the greater the result of this statistic, the greater its explanatory power. According to Hair, J. F., Ringle, C. M., and Sarstedt, M. (2011), R2 classifies it with the following values: 0.75 substantial, 0.5 moderate and 0.25 weak. For the purposes of this investigation, the following values were obtained: Y1 Financial Administrator $=\mathrm{f}(0.6$ Analysis of the Environment +0.3 Accuracy of Information $+e$ ) with a predictive power of 0.9 . The environment analysis being the most important variable.

\section{Beta Coefficients:}

The trajectory of the coefficients determines the relationship of the dependent variables with the independent ones. The signs show the relationship, that is, if the sign is positive it means that they move in the same direction, instead if the sign is negative they indicate an inverse relationship. 
In the case of the investigation, the Betas were 0.6 (Y1X1) and 0.3 (Y1X2). The higher the reliability coefficient will be $97 \%$ and an error less than $3 \%$. The greater the significance of the sample, the better the predictive capacity between the causal relationships of the proposed model.

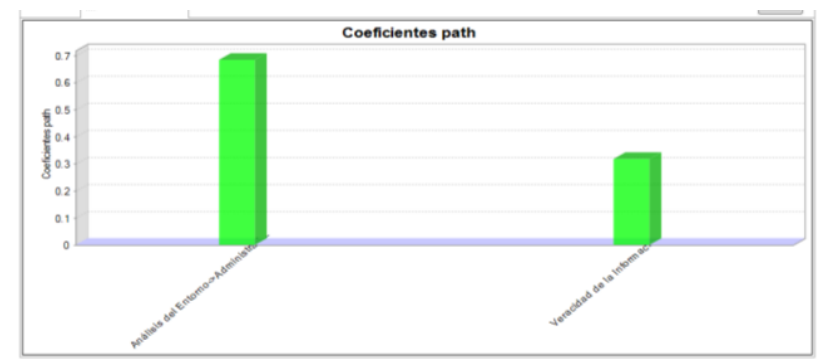

Figure 2 Beta Coefficients

Own Elaboration with SmartPLS, 2019

\section{Value and Statistics t:}

The p-value shows the significance with which the relationships can be accepted which would have to be less than 0.05 and the value of $t$ to be significant has to be greater than 1.76 . In the case of the investigation, both criteria are met as shown in the following Table 1. Hypothesis Verification.

\begin{tabular}{|c|c|c|}
\hline Hypothesis & $\begin{array}{c}\mathbf{P} \\
\text { value }\end{array}$ & $\mathbf{t}$ \\
\hline $\begin{array}{l}\text { H1: The Financial Administrator through } \\
\text { the cost system positively impacts the } \\
\text { economic performance of the } \\
\text { organization with the use of } \\
\text { environmental analysis. }\end{array}$ & 0.00 & 10.2 \\
\hline $\begin{array}{l}\text { H2: The Financial Administrator through } \\
\text { the cost system positively impacts the } \\
\text { economic performance of the } \\
\text { organization with the use of truthful } \\
\text { information. }\end{array}$ & 0.00 & 4.7 \\
\hline
\end{tabular}

Table 1 Hypothesis Testing, Authors, 2019

\section{Graphic Model}

With the results obtained, we proceeded to develop and establish the causal relationships which can be seen in the following Figure 1. Graphic Model.

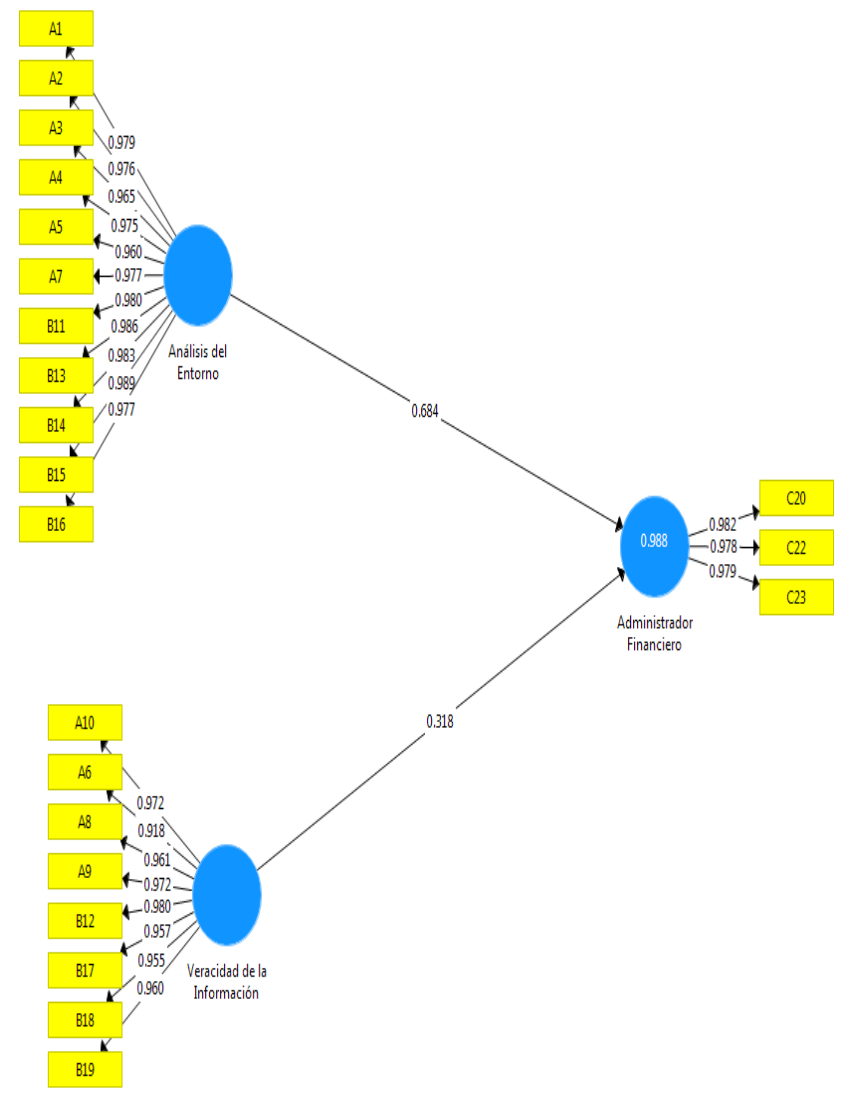

Figure 3 Graphic Model

Own Elaboration with SmartPLS, 2019

\section{Conclusions}

As part of the concerns of current researchers in administrative economic sciences, it has been determined to make contributions to knowledge that positively impact the regions in which they are carried out; That is why the commitment to encourage applied research which could be useful to entrepreneurs in the textile sector of Mpymes of the municipality of Cajeme, Sonora.

Government initiatives are focused on innovation, in such a way that companies can strengthen their productive capacities through the use of financial tools. One of these innovations is cost systems, which aim to facilitate and support decision-making, as well as the detection of opportunities for improvement.

Derived from the results of the investigation, the following findings were found: There is a positive relationship between the decisions made by the financial manager with the use of a cost system and the analysis of the environment; and also within this model it is the most important (there is statistically significant evidence with a $p$-value of 0 and a statistical $t$ of 10.2). 
This indicates that the financial performance of an organization can be strongly affected by the internal and external conditions that the organization is going through. This finding reinforces what was cited by Guerrero (2004) and Gómez y Herrera (2014).

Similarly, it was found that the financial administrator through the cost system positively impacts the economic performance of the organization with the use of truthful information (there is statistically significant evidence with a p-value of 0 and a statistical $t$ of 4.7). This reveals that the information obtained through the tool must be as objective as possible, since if falsehood is committed, the decisions taken will have an adverse effect on the objectives of the organization. This conclusion is reinforced with the approaches of Rincón and Fernando, (2010) and Rincón, Lasso and Parrado (2012).

In conclusion, it can be affirmed that the financial administrator of an organization plays a key role in its performance, since through the appropriate management of the cost system, it can obtain pertinent information that will help it make better decisions about the conditions of the organization. environment (mainly in relation to competitors, losses, among others) and to obtain truthful information that is reliable to support the objectives previously set for the economic agent. In future research, the sample could be extended to larger companies to see if there are significant differences between the capacity of larger-scale organizations compared to larger-scale organizations.

\section{References}

Ángulo, M. A. (2001). Análisis del Cluster Textil en el Perú: Industria Textil. Recuperado de

http://sisbib.unmsm.edu.pe/bibvirtualdata/Tesis/ Ingenie/angulo_lm/cap2.PDF

Arroyo, M. E. y Cárcamo, M. (2010). La evolución histórica e importancia económica del sector textil y del vestido en México. Economía y Sociedad, 14(25), 53. Recuperado de http://www.redalyc.org/pdf/510/51015546004.p df

Cedeño, F., Coloma, R., \& Zamora, V.(2016). Sistema de costos en las PYMES. Revista Caribeña de Ciencias Sociales, (2016_11).
Consejo Mexicano de Normas de Información Financiera (CINIF). (2018). Normas de Información Financiera: A-4 Características cualitativas de los estados financieros.

Daza, R., y Herminia, F. (2018). Administración financiera.

Del Río, C. y Del Rio, C. (2004). Costos para Administradores y Dirigentes (2da edición). México: International Thomson Editores.

Díaz, E. (2005). El mercado de trabajo en la frontera norte frente al cierre de empresas maquiladoras. Frontera Norte, 17(34), 144-145. Recuperado de http://www.scielo.org.mx/pdf/fn/v17n34/v17n3 4a5.pdf

Díaz, E. (2009). Mercado de trabajo e industria maquiladora en Sonora y la frontera norte. Región y sociedad, 21(44), 47. Recuperado de http://www.scielo.org.mx/pdf/regsoc/v21n44/v2 1n44a2.pdf

Estadístico Nacional de Unidades Económicas (2019). Fabricación de prendas de vestir. 01/08/2019.

Recuperado: https://www.inegi.org.mx/app/descarga/?ti=6 García, J. (2014). Contabilidad de costos (4ta edición). México: McGRAW-HILL INTERAMERICANA.

Gobierno del Estado de Sonora. (2016). Informe Anual de Trabajo 2016. 01/08/2019, de Secretaría de Economía Sitio web: http://www.economiasonora.gob.mx/portal/desc argas/se_informe_anual_2016.pdf

Gómez, J. M., y Herrera, T. J. F. (2014). Análisis de los factores determinantes de la cultura organizacional en el ambiente empresarial. Entramado, 10(1), 96-105.

Gómez, O. (2005). Contabilidad de costos (5ta edición). Colombia: McGRAW-HILL INTERAMERICANA. 
González, N. E., Aceves, J. N., López, M. E., Navarro, E. M. \& Moreno, M. D. (2018). Diagnóstico de sistemas de información de costos como fundamento en la generación de estrategias de mejora para el desarrollo de las PYMES. Revista de Negocios \& PyMES, 4(14), 22. Recuperado de http://www.ecorfan.org/spain/researchjournals/ Negocios_y_PyMES/vol4num14/Revista_de_N egocios_\&_PyMES_V4_N14_3.pdf

Guerrero, E. (2004). Las pymes y su problemática empresarial. Análisis de casos. Investigacion en Administracion en America Latina, 296.

Hair, J. F., Ringle, C. M., y Sarstedt, M. (2011). PLS-SEM: Indeed a silver bullet. Journal of Marketing theory and Practice, 19(2), 139-152 Horngren, C., Datar, S. y Rajan, M. (2012.). Contabilidad de costos. Un enfoque gerencial (14ta edición). México: PEARSON EDUCACIÓN.

Huicochea, E. (2010). Contabilidad de costos (3a edición). México: EDITORIAL TRILLAS. Keremitsis, D. (1973). La industria textil mexicana en el siglo xix. SEPTENTAS: México.

Lara, B., Velásquez, L. \& Rodríguez, L. I. (2007). Especialización económica en Sonora: Características y retos al inicio del nuevo milenio. Región y sociedad, 9(Número especial), 28. Recuperado de http://www.scielo.org.mx/pdf/regsoc/v19nspe/v 19nspea3.pdf

Merlo, E., Reinoso, N., Rubino, M. S. \& Ruggeri, Y. (2013). Los costos y las tomas de decisiones. Argentina: Universidad Nacional de Cuyo. Recuperado de http://bdigital.uncu.edu.ar/objetos_digitales/524 0/merlofinal.pdf

Monge, E. C. (2010). Las estrategias competitivas y su importancia en la buena gestión de las empresas. Revista de Ciencias Económicas.

Ortega, A. (2012). Contabilidad de costos (6ta edición). México: LIMUSA.

PROMÉXICO. (2018). Industrial textil y de la confección en México. Recuperado de http://www.promexico.gob.mx/template/ciie/do cs/sectores/industria-textil-y-de-la-confeccionen-mexico.pdf
Reyes, E. (2016). Contabilidad de costos 1 (4ta edición). México: LIMUSA.

Rincón Soto, C. A., Lasso Marmolejo, G., y Parrado Bolaños, Á. E. (2012). Contabilidad siglo XXI. Bogota: Ecoe Ediciones, 370.

Rincón, C. A., y Fernando, V. V. (2010). Costos: decisiones empresariales. Ecoe Ediciones.

Ríos, M. (2014). Método de diagnóstico para determinar el sistema de costes en una pyme. Un caso de estudio. RIGC, 12(24), 13-22.

Román, C. (2012). Fundamentos de administración financiera. México, México $D F$ : Editorial Red Tercer Milenio.
MILLANES-MORENO, María Dolores, RUIZ-PEREZ, Roberto, VALENZUELA-REYNAGA, Rodolfo and VÁZQUEZ-JIMENEZ Imelda Lorena. Diagnosis of the Cost System in SME companies in the textile sector of South Sonora, Mexico. Journal-Business Administration-Marketing; Accounting. 2019 